\title{
ANALISIS PENGARUH SISTEM PERPAJAKAN DAN PEMERIKSAAN PAJAK TERHADAP PENGGELAPAN PAJAK PADA PERUSAHAAN HOME INDUSTRY DI KOTA PADANG
}

\author{
Silvia Reswina \\ Dewi Zulvia, SE, MM \\ Akuntansi, STIE "KBP" Padang \\ Email: silviareswina07@gmail.com \\ dewizulvia@akbpstie.ac.id
}

\begin{abstract}
On the pattern of finance national development and public expenditure, tax income is very important, therefore the government has try attempted to improve revenue from tax. But, the fact many assessable not obey to tax law by doing tax evasion. Currently the government try to reduce tax fraud. This study aimed to knowing the influence tax system and tax investigation to tax evasion. The kind this study is kuantitatif, population in this study is home industry firm in Padang city, sample taken is 44 respondents and served accounting and manager. Sample technique taken by purposive sampling and then use IBM SPSS Statistic 23 to processed data. Processing data method use multiple analysis regression.

The result this study is influence that variable tax system and tax investigation affect significant to tax evasion with sig variabel $t<0,05$.
\end{abstract}

Keywords: Tax System, Tax Investigation and Tax Evasion. 


\section{PENDAHULUAN}

Indonesia merupakan negara berkembang yang melaksanakan pembangunan nasional demi meraih kesejahteraan masyarakat. Dalam melaksanakan pembangunan ini, pemerintah membutuhkan dana yang cukup. Dana ini diperoleh dari berbagai macam sumber penerimaan negara, salah satunya adalah dari pajak. Semua penerimaan yang berasal dari digunakan untuk mensejahterakan rakyat, karena pajak bersifat dinamis dan selalu mengikuti perkembangan kehidupan ekonomi dan sosial, sehingga pajak yang dibayarkan oleh masyarakat dan untuk masyarakat. Oleh sebab itu, wajib pajak harus membayar pajak sesuai dengan kewajibannya.

Dalam perkembangannya, pajak mengalami perubahan dalam peraturannya. Peraturan yang ditetapkan di Indonesia memiliki beberapa perubahan yang sesuai dengan kondisi negara dalam berbagai kebijakan. Salah satunya adalah kebijakan dalam perpajakan adalah sistem pemungutan pajak dilakukan dengan Self Assessment System, yaitu suatu pemungutan pajak yang memberi wewenang wajib pajak dalam menentukan sendiri jumlah pajak terhutang, menghitung pajak yang sudah dibayar sendiri atau dipotong oleh pihak ketiga, melunasi kekurangan pajaknya dan/atau melaporkan pemenuhan kewajiban perpajakannya di kantor Direktoral Jenderal Pajak. Pemerintah telah memberikan kepercayaan kepada wajib pajak untuk mengurus sendiri utang pajak mereka. Namun dengan sistem ini $m$ wajib pajak bisa dengan sengaja melakukan kecurangan dengan mengisi laporan tidaak benar (Saraswati, 2013) dan membayar pajak sekecil mungkin, sehingga wajib pajak akan semakin cenderung dalam melakukan tindakan penyuludupan pajak yang disebut penggelapan pajak dan ini melanggar peraturan perundangan-undangan perpajakan.

Penggelapan pajak adalah cara yang digunakan oleh wajib pajak untuk menghindar dari kewajiban pajak yang sebenarnya dan ini merupakan perbuatan yang melanggar peraturan perundang-undangan perpajakan, sehingga bisa menyebabkan berbagai macam akibat, seperti halnya dalam bdang kehidupan masyarakat, antara lain bidang keuangan, ekonomi, dan psikologi (Siahaan, 2010: 110). Misalnya, wajib pajak tidak melaporkan pendapatan yang sebenarnya dan menghindar untuk menyatakan kekayaan mereka dengan cara tidak mau membayar pajak atau mereka lebih memilih untuk menyimpan uang mereka untuk diri mereka sendiri.

Penggelapan pajak adalah Tindakan yang melanggar Undang-undang Perpajakan, dengan menyampaikan jumlah SPT penghasilan yang lebih rendah daripada yang seharusnya di satu pihak dan melaporkan biaya yang lebih besar daripada yang sebenarnya dipihak ketiga. Tindak pengelapan pajak dapat dilihat dari beberapa kriteria yaitu wajib pajak tidak melaporkan harta yang sesungguhnya, membayar beban pajak terutang tidak sesuai dengan yang telah dibebankan, dan yang lebih parah alah tidak melpaorkan SPT.

Kenyataan dilapangan yang terjadi adalah kesadaran wajib pajak dalam membayar pajak masih rendah, hal ini dapat dilihat dari dikarenakan mereka berpikiran bahwa uang yang dikeluarkan untuk memabayar pajak belum sepenuhnya dirasakan secara adil oleh rakyat. Rendahnya kesadaran wajib pajak terlihat dari realisasi penerimaan pajak. Empat tahun terakhir realisasi penerimaan 
pajak belum mencapai target yang ditentukan, hal ini disebabkan karena wajib pajak tidak membayar beban pajak terutang 100\%. Berdasarkan target dan realisasi penerimaan pajak pada tahun 2013-2016. Penerimaan pajak di Indonesia belum mencapai target yang telah ditetapkan. Penerimaan pajak di Indonesia belum mencapai target yang telah ditetapkan. Pada tahun 2013 persentase penerimaan pajak sebesar 92,57\%, sedangkan untuk tahun 2014, 2015 dan 2016 mengalami penurunan yaitu sebesar $91,56 \%, 81,96 \%$ dan $81,60 \%$.

Salah satu faktor tidak tercapainya target penerimaan pajak adalah masih rendahnya kesadaran Wajib Pajak karena belum dirasakan secara nyata hasil dari pajak yang dibayarkan oleh wajib pajak, kemudian masih adanya Wajib Pajak yang membayar beban pajak terutang tidak sesuai dengan yang telah dibebankan. Di Indonesia banyak terjadi kasus penggelapan pajak (tax evasion), misalnya kasus Gayus pada tahun 2009 yang sangat membuat heboh media massa karena merugikan negara sangat banyak, kemudian kasus Suwir Laut pada tahun 2011 yang melibatkan PT Asian Agri Group serta kasus Johny Basuki dan Dhana Widyatmika pada tahun 2012 (Rahman, 2013). Banyaknya kasus penggelapan pajak yang terjadi menyebabkan masyarakat tidak mau untuk melakukan kewajiban perpajakannya dengan benar sesuai peraturan perundang-undangan. Usaha Wajib Pajak untuk meminimalkan beban pajak terutangnya salah satunya dilatarbelakangi oleh kasus penggelapan dana pajak atau dengan kata lain takut jika uangnya dikorupsi oleh pegawai pajak (Friskianti, 2014). Penyebab penggelapan pajak (tax evasion) lainnya yaitu karena Wajib Pajak kurang sadar tentang kewajiban bernegara, kurang patuh pada peraturan, dan wajib pajak merasa apa yang dibayarkan tidak sesuai dengan apa yang mereka terima.

Pada Penelitian sebelumnya Suminarsasi dan Supriyadi (2011), Irma Suryani Rahman (2013), Ardian dan Pratomo (2015), dan Ayu Vanny Saraswati (2013) menyatakan bahwa masih banyak Wajib Pajak yang tidak mematuhi undang-undang pajak dengan melakukan penggelapan pajak. Apabila sistem perpajakan dan pemeriksaan pajak dapat ditingkatkan lagi sesuai dengan kemampuan wajib pajak, maka semakin kecil kemungkinan wajib pajak untuk melakukan tidakan penggelapan pajak.

Berdasarkan uraian yang telah dijelakan diatas, maka peneliti termotivasi untuk menganalisa lebih jauh mengenai pengaruh sistem perpajakan dan pemeriksaan pajak terhadap penggelapan pajak. Oleh karena itu, peneliti melakukan penelitian ini dengan judul "Analisis Pengaruh Sistem Perpajakan dan Pemeriksaan Pajak terhadap Penggelapan Pajak pada Perusahaan Home Industry di Kota Padang”.

Rumusan masalah dalam penelitian ini adalah :

1. Apakah sistem perpajakan berpengaruh terhadap penggelapan pajak?

2. Apakah pemeriksaan pajak berpengaruh terhadap penggelapan pajak?

Tujuan dalam penelitian ini adalah :

1. Untuk mengetahui pengaruh sistem perpajakan terhadap penggelapan pajak?

2. Untuk mengetahui pengaruh pemeriksaan pajak berpengaruh penggelapan pajak?

\section{TINJAUAN PUSTAKA}




\section{Sistem Perpajakan}

Sistem yang dipakai oleh Indonesia dalam sistem perpajakannya memakai self assessment system, dimana Wajib Pajak yang berperan aktif dalam menghitung, melaporkan dan membayar pajaknya.

Berdasarkan pengujian sistem perpajakan yang dilakukan oleh Suminarsasi dan Supriyadi (2011) dan Ardian dan Pratomo (2015) menunjukan Sistem perpajakan mempunyai pengaruh terhadap penggelapan pajak dan adanya indikasi nilai yang negatif. Hal ini berarti jika sistem perpajakan baik, jelas, adil dan transparan serta dasar pengenaannya sesuai dengan kemampuan wajib pajak, maka kecil kmungkinan untuk melakukan tindakan penggelapan pajak.

\section{Pemeriksaan Pajak}

Menurut Hidayat (2012) dalam bukunya "Pemeriksaan Pajak" adalah sebagai berikut: Pemeriksaan adalah serangkaian kegiatan menghimpun dan mengolah data, keterangan, atau bukti yang dilaksanakan secara objektif dan profesional berdasarkan suatu standar pemeriksaan untuk menguji kepatuhan pemenuhan kewajiban perpajakan dan tujuan lain dalam rangka melaksanakan ketentuan perundang - undangan perpajakan.

Berdasarkan pengujian pemeriksaan pajak yang dilakukan oleh Irma Suryani Rahman (2013) dan Vanny Ayu Saraswati (2013) menunjukan bahwa Pemeriksaan pajak mempunyai pengaruh terhadap penggelapan pajak. Artinya semakin baik pemeriksaan yang dilakukan maka semakin berkurang tingkat penggelapan pajak yang dilakukan oleh wajib pajak.

\section{Penggelapan Pajak}

Menurut Siahaan (2010: 110) mendefinisikan penggelapan pajak merupakan cara yang digunakan oleh wajib pajak dalam menghindar dari kewajiban pajak yang sesungguhnya dan hal ini adalah perbuatan yang melanggar undang-undang perpajakan, sehingga bisa menyebabkan berbagai macam akibat, yaitu dalam bidang kehidupan masyarakat, antara lain bidang keuangan, ekonomi, dan psikologi."

Masri dan Martani (2012) menyatakan bahwa pembahasan mengenai penggelapan pajak (tax evasion) merupakan: "Usaha-usaha memperkecil jumlah pajak dengan melanggar ketentuan-ketentuan pajak yang berlaku. Pelaku tax evasion dapat dikenakan sanksi administratif maupun sanksi pidana".

\section{METODOLOGI PENELITIAN}

\section{Jenis Penelitian}

Jenis penelitian yang digunakan adalah penelitian kuantitatif. Penelitian kuantitatif berlandasan pada filsafat yang telah memenuhi kaidah-kaidah ilmiah dan dikembangkan berbagai iptek baru serta data penelitian berupa angka-angka 
dan analisis menggunakan prosedur statistik (Sugiyono, 2016: 7). Data yang terkumpul diolah menggunakan alat analisis IBM SPSS Statistics 23, untuk menentukan hasil dari masing-masing hipotesis yang telah ditetapkan. Dalam penelitian skripsi ini ada tiga variabel sebagai berikut:

a. Independen variabel (X1) dalam penelitian ini adalah sistem perpajakan.

b. Independen variabel (X2) dalam penelitian ini adalah pemeriksaan pajak.

c. Dependen variabel (Y) dalam penelitian ini adalah penggelapan pajak.

\section{Populasi dan Sampel}

Populasi yaitu wilayah generalisasi yang terdiri atas obyek atau subjek yang mempunyai kualitas atau karakteristik tertentu yang ditetapkan oleh peneliti untuk dipelajari, kemudian diambil kesimpulan (Sugiyono, 2016:18) Dalam penelitian ini populasinya adalah Wajib Pajak Badan yang bergerak dalam bidang Home Industry di Kota Padang. Tidak semua perusahaan home industry di Kota Padang menjadi objek dalam penelitian ini karena jumlahnya sangat besar dan guna efisiensi waktu.

Sampel penelitian adalah bagian dari jumlah dan karakteristik yang dimiliki oleh pupolasi tersebut (Sugiyono, 2016: 81). Teknik pengambilan sampel yang digunakan dalam penelitian ini adalah sampling jenuh.

\section{Jenis dan Sumber Data}

Kuesioner merupakan teknik pengumpulan data yang dilakukan dengan cara memberikan pertanyaan atau pernyataan tertulis yang ditujukan pada responden untuk dijawabnya (Sugiyono, 2016: 142). Sumber data primer pada penelitian ini diambil secara langsung dari wajib pajak yang memiliki usaha, melalui kuesioner yang berisi pertanyaan yang bersifat pribadi.

Jenis data dalam penelitian ini adalah skala interval yang menggunakan metode tranformasi. Metode tranformasi yang digunakan yaitu Method of Successive Interval dengan bantuan makro mini tab. Variabel yang akan diukur dan diamati menjadi indikator variabel yang dapat berupa kuesioner atau angket yang bertujuan untuk mengetahui pendapat responden (Ghozali, 2016: 45)

\section{Teknik Pengumpulan Data}

Pengumpulan data kuesioner dilakukan dengan teknik Personally administered questionnaires, yaitu kuesioner disampaikan dan dikumpulkan langsung oleh peneliti.

\section{Teknik Analisis Data}

\section{Uji Validitas}

Uji Validitas digunakan untuk mengukur sah atau valid tidaknya suatu kuesioner. Suatu kuesiner dikatakan valid apabila pertanyaan pada kuesioner mampu unuk mengungkapkan sesuatu yang akan diukur oleh kuesioner tersebut (Ghozali (2016: 52). 


\section{Uji Reliabiltas}

Uji reliabilitas adalah alat ukur untuk mengukur suatu kuesioner yang merupakan indikator dari variabel atau konstruk. Suatu kuesioner dikatakan reliabel atau handal jika jawaban seorang terhadap pernyataan adalah konsisten atau stabil dari waktu ke waktu (Ghozali, 2016: 47).

\section{Uji Asumsi Klasik}

\section{a. Uji Normalitas}

Uji normalitas bertujuan untuk menguji apakah dalam model regresi variabel dependen (terikat) dan variabel independen (bebas) mempunyai distribusi normal atau tidak. Model regresi yang baik adalah model regresi yang memiliki distribusi data normal atau mendekati normal (Priyastama, 2017: 117)

\section{b. Uji Multikolinearitas}

Uji Multikolinearitas ini bertujuan untuk menguji apakah ditemukan adanya korelasi yang sempurna atau mendekati sempurna antar variabel bebas (independen) pada model regresi (Priyastama, 2017: 122). Model regresi yang baik adalah yang tidak terjadi korelasi diantara variabel bebas. Pengujian multikolinearitas dilihat dari besaran VIF (Variance Inflation Factor) dan Tolerance, dengan nilai Tolerance $>0,1$ dan nilai VIF $<10$ maka menunjukan bahwa tidak terjadi multikolinearitas (Priyastama, 2017: 123).

\section{c. Uji Heterokedastisitas}

Uji Heteroskedastisitas bertujuan untuk menguji apakah dalam model regresi terjadi ketidaksamaan variansi dari residual satu pengamatan ke pengamatan yang lain . Model regresi yang baik adalah tidak terjadi heteroskedastisitas (Priyastama, 2017: 125).

\section{Uji Hipotesis}

Secara statistik, model regresi dapat diukur melalui nilai koefisien determinasi $\left(\mathrm{R}^{2}\right)$, nilai statistik $\mathrm{t}$ dan nilai statistik $\mathrm{F}$. Apabila nilai uji statistiknya berada di daerah kritis (Ha diterima) maka perhitungan tersebut signifikan. Sebaliknya bila nilai uji statistiknya berada di daerah (Ha ditolak) maka perhitungannya tidak signifikan.

\section{Definisi Operasional Variabel}

\section{Variabel Indenpenden / Bebas \\ a. Sistem Perpajakan (X1)}

Sistem Perpajakan adalah suatu sistem pemungutan pajak yang merupakan perwujudan dari pengabdian dan peran serta WP secara langsung atau bersama- 
sama dalam melaksanakan kewajiban perpajakan yang diperlukan untuk pembiayaan penyelenggaraan Negara dan pembangunan nasional.

\section{b. Pemeriksaan Pajak (X2)}

Pemeriksaan pajak dilaksanakan dalam rangka melaksanakan ketentuan peraturan perundang-undangan perpajakan.

\section{Variabel Denpenden / Terikat \\ Penggelapan Pajak}

Menurut (Mardiasmo,2009) mendefinisikan penggelapan pajak (tax evasion) Adalah usaha yang dilakukan oleh wajib pajak dalam meringankan beban pajak dengan cara melanggar peraturan perundang-undangan perpajakan.

\section{HASIL DAN PEMBAHASAN}

Jumlah kuesioner yang dibagikan sebanyak 44 kuesioner dan kuesioner diantar langsung ke perusahaan home industry. Dari jumlah kuesioner yang diperoleh, terdapat 6 lembar kuesioner yang tidak diisi dengan lengkap oleh responden, sehingga data yang dapat diolah sebanyak 38 lembar.

\section{Hasil Uji Validitas Data}

Uji validitas dalam penelitian ini yaitu dengan melakukan KMO and Bartlett's Test. Nilai yang dapat diterima adalah diatas 0,5. Nilai Bartlett's test yang dapat diterima adalah jika signifikansi dibawah 0,05 dan yang paling bagus jika dibawah 0,01 .

\section{Tabel 1}

Hasil Uji Validitas

\begin{tabular}{|l|c|c|c|}
\hline \multicolumn{1}{|c|}{ Variabel } & $\begin{array}{c}\text { Batasan } \\
\text { Nilai }\end{array}$ & $\begin{array}{c}\text { KMO } \\
\text { and } \\
\text { Bartlett's } \\
\text { Test }\end{array}$ & Keputusan \\
\hline $\begin{array}{l}\text { Sistem } \\
\text { Perpajakan }\end{array}$ & 0,50 & 0,573 & Valid \\
\hline $\begin{array}{l}\text { Pemeriksaan } \\
\text { Pajak }\end{array}$ & 0,50 & 0,511 & Valid \\
\hline $\begin{array}{l}\text { Penggelapan } \\
\text { Pajak }\end{array}$ & 0,50 & 0,753 & Valid \\
\hline \multicolumn{3}{|l|}{ Sumber: Data Primer diolah dengan SPSS23 (2017) } \\
\hline
\end{tabular}

Dilihat dari Tabel 1, sistem perpajakan dan pemeriksaan pajak dinyatakan valid karena nilai $\mathrm{KMO}>0,05$

\section{Hasil Uji Reliabilitas}


Uji reliabilitas ini diukur dengan menggunakan Cronbach Alpha. Dimana hasil yang dihasilkan lebih besar dari 0.60 , maka instrumen yang digunakan dapat dikatakan reliabel.

Tabel 2

Hasil Uji Reliabilitas

\begin{tabular}{|l|c|c|c|}
\hline Variabel & $\begin{array}{c}\text { Batas } \\
\text { an } \\
\text { Nilsai }\end{array}$ & $\begin{array}{c}\text { Cron } \\
\text { bach's } \\
\text { Alpha }\end{array}$ & Keputusan \\
\hline $\begin{array}{l}\text { Sistem } \\
\text { Perpajakan }\end{array}$ & 0,60 & 0,755 & Reliabel \\
\hline $\begin{array}{l}\text { Pemeriksaan } \\
\text { Pajak }\end{array}$ & 0,60 & 0,713 & Reliabel \\
\hline $\begin{array}{l}\text { Penggelapan } \\
\text { Pajak }\end{array}$ & 0,60 & 0,757 & Reliabel \\
\hline
\end{tabular}

Sumber: Data Primer diolah dengan SPSS 23 (2017)

Dari tabel 2, menunjukan bahwa seluruh variabel mempunyai Cronbach Alpha yang cukup besar yaitu berada diatas 0,60 , sehingga dapat dikatakan semua pernyataan dalam kuesioner ini adalah reliabel.

\section{Hasil Uji Asumsi Klasik}

\section{a. Hasil Uji Normalitas}

Uji normalitas memilki tujuan untuk melihat apakah nilai residual terdistribusi normal atau tidak, dilakukan dengan menggunakan One Sample Kolmogorpv-Smirnov, dapat dikatakan normal apabila nilai signifikansi $>0,05$..

\section{Tabel 3}

\section{Hasil Uji Normalitas}

\begin{tabular}{|l|c|}
\hline & $\begin{array}{c}\text { Standardized } \\
\text { Residual }\end{array}$ \\
\hline Asymp. Sig. (2-tailed) &, $200^{\mathrm{c}, \mathrm{d}}$ \\
\hline
\end{tabular}

Dapat dilihat pada table 3, bahwa besarnya nilai Kolmogorov-Smirnov Test menghasilkan Asymponic Significance lebih besar dari 0,05 yaitu 0,200> 0,05 , sehingga disimpulkan bahwa model regresi telah memenuhi asumsi kenormalan.

\section{b. Hasil Uji Multikolinearitas}

Pengujian multikolinearitas dapat dilihat melalui nilai Variance Inflation Factors (VIF) dan nilai tolerance pada output yang dihasilkan oleh SPSS. Kriteria pengujiannya adalah apabila nilai VIF $<10$ atau tolerance $>0,10$ maka tidak terdapat multikolinearitas diantara variabel independen. 
Tabel 4

Coefficients $^{\mathrm{a}}$

\begin{tabular}{|l|c|c|}
\hline \multirow{2}{*}{ Variabel } & \multicolumn{2}{|c|}{$\begin{array}{c}\text { Collinearity } \\
\text { Statistics }\end{array}$} \\
\cline { 2 - 3 } & Tolerance & VIF \\
\hline $\begin{array}{l}\text { Sistem } \\
\text { Perpajakan }\end{array}$ & 0,999 & 1,001 \\
\hline $\begin{array}{l}\text { Pemeriksaan } \\
\text { Pajak }\end{array}$ & 0,999 & 1,001 \\
\hline
\end{tabular}

Pada Tabel 4, dapat dilihat bahwa seluruh variabel dalam penelitian ini memiliki nilai tolerance untuk seluruh variabel > 0,01 dan nilai Variance Inflation Factors (VIF) < 10, sehingga dapat ditarik kesimpulan bahwa seluruh variabel independen dalam penelitian ini tidak mengalami multikolinearitas pada model regresi.

\section{c. Hasil Uji Heteroskedastisitas}

Uji heteroskedastisitas dilakukan dengan menggunakan uji Gleiser. Apabila nilai sig > 0,05 maka data terbebas dari heteroskedastisidas, sedangkan jika nilai sig $<0,05$ maka data terkena heteroskedastisitas dan tidak bisa dilakukan analisis lebih lanjut.

Tabel 5

Hasil Uji Heteroskedastisitas - Gletser

\begin{tabular}{|l|c|c|l|}
\hline Variabel & T & sig & Keterangan \\
\hline $\begin{array}{l}\text { Sistem } \\
\text { Perpajakan }\end{array}$ & 1,994 & 0,054 & $\begin{array}{l}\text { Bebas } \\
\text { Heteroskedas } \\
\text { tisitas }\end{array}$ \\
\hline $\begin{array}{l}\text { Pemeriksaan } \\
\text { Pajak }\end{array}$ & 1,314 & 0,198 & $\begin{array}{l}\text { Bebas } \\
\text { Heteroskedas } \\
\text { tisitas }\end{array}$ \\
\hline
\end{tabular}

Dillihat pada table 5, hasil uji heteroskedastisitas kedua variabel independen memiliki nilai sig $>0,05$, sehingga dapat ditarik kesimpulan bahwa data terbebas dari heteroskedastisitas.

\section{Regresi Linear Berganda}

Analisis regresi linear berganda merupakan hubungan secara linear antara dua atau lebih variabel independen dengan variabel dependen.

Tabel 6

Hasil Regresi Linear Berganda

\begin{tabular}{|c|c|c|}
\hline \multirow{2}{*}{ Model } & \multicolumn{2}{|c|}{$\begin{array}{c}\text { Unstandardized } \\
\text { Coefficients }\end{array}$} \\
\cline { 2 - 3 } & $\mathrm{B}$ & Std. Error \\
\hline (Constant) & 25,179 & 6,540 \\
\cline { 2 - 3 } Sistem & 0,947 & 0,228 \\
\cline { 2 - 3 }
\end{tabular}




\begin{tabular}{|c|c|c|}
\hline \multicolumn{3}{|l|}{ Perp } \\
\hline $\begin{array}{c}\text { Pemeriksaa } \\
\text { n Pajak }\end{array}$ & $-0,951$ & 0,269 \\
\hline
\end{tabular}

Berdasarkan Tabel 4.13. yang menunjukkan hasil regresi linear berganda untuk menguji hipotesis 1 dan hipotesis 2, maka dapat dibuat persamaan sebagai berikut:

$\mathrm{Y}=\mathrm{a}+\mathrm{b} 1 \mathrm{X} 1+\mathrm{b} 2 \mathrm{X} 2$

$\mathrm{Y}=25,179+0,947 \mathrm{X} 1-0,951 \mathrm{X} 2$

\section{Uji Hipotesis}

\section{a.Uji F}

Kriteria pengujiannya adalah jika nilai $\mathrm{F}$ hitung $>\mathrm{F}$ tabel atau sig $<\alpha$ $(0,05)$, maka dapat diartikan variabel bebas (independen) berpengaruh signifikan variabel terikat (dependen) secara bersama-sama.

\begin{tabular}{|c|c|c|c|}
\hline \multicolumn{4}{|c|}{$\begin{array}{c}\text { Tabel } 7 \\
\text { Hasil Uji F } \\
\text { ANOVA }^{\mathrm{a}} \\
\end{array}$} \\
\hline Model & $\begin{array}{l}\text { Sum of } \\
\text { Squares }\end{array}$ & $\mathrm{F}$ & Sig. \\
\hline \multirow{3}{*}{$\begin{array}{c}\text { Regression } \\
\text { Residual } \\
\text { Total }\end{array}$} & 464,008 & 15,413 &, $000^{\mathrm{b}}$ \\
\hline & 526,834 & & \\
\hline & 990,842 & & \\
\hline
\end{tabular}

Berdasarkan hasil uji Anova pada Tabel 7, menunjukkan bahwa nilai $\mathrm{F}$ hitung sebesar 15,413 dengan nilai sig adalah sebesar 0,000. Hal ini menunjukkan bahwa $0,000<\alpha(0,05)$, artinya adalah variabel independen mempunyai pengaruh signifikan secara simultan (bersama-sama) terhadap variabel dependen.

\section{b.Uji T}

Uji $\mathrm{T}$ digunakan untuk mengetahui apakah variabel independen secara parsial (individu) berpengaruh terhadap variabel dependen. Pengujian dilakukan dengan menggunakan Significance level 0,05, apabila significane level berada diatas 0,05 maka hipotesis ditolak (variabel independen tidak berpengaruh secara parsial terhadap variabel dependen).

Tabel 8 


\begin{tabular}{|l|c|c|}
\hline \multicolumn{1}{|c|}{ Model } & $\mathrm{t}$ & Sig. \\
\hline $\begin{array}{l}\text { (Constant) } \\
\begin{array}{l}\text { Sistem } \\
\text { Perpajakan } \\
\text { Pemeriksaan } \\
\text { Pajak }\end{array}\end{array}$ & 3,850 & 0,000 \\
\cline { 2 - 3 } & $-3,148$ & 0,000 \\
\hline
\end{tabular}

Hasil uji $\mathrm{T}$ menunjukan nilai signifikansi $<0,05$, artinya $\mathrm{H}_{0,1}$ ditolak dan $\mathrm{H}_{1,1}$ diterima, maka dapat dikatakan bahwa sistem perpajakan dan pemeriksaan pajak secara parsial memiliki pengaruh signifikan terhadap penggelapan pajak.

\section{Uji Koefisien Determinasi $\left(\mathbf{R}^{2}\right)$}

Uji koefisien determinasi ini digunakan untuk mengetahui seberapa besar pengaruh variabel independen terhadap variabel dependen secara keseluruhan dan besarnya tersebut bisa didapat dengan uji koefisien determinasi dengan melihat nilai $R$ Square.

\section{Tabel 9}

\section{Hasil Uji Koefisien Determinasi $\left(\mathbf{R}^{2}\right)$}

\begin{tabular}{|r|c|c|c|c|}
\multicolumn{1}{|c}{ Model Summary } \\
\hline Model & $\mathrm{R}$ & $\begin{array}{c}\mathrm{R} \\
\text { Square }\end{array}$ & $\begin{array}{c}\text { Adjusted } \\
\text { R Square }\end{array}$ & $\begin{array}{c}\text { Std. } \\
\text { Error of } \\
\text { the } \\
\text { Estimate }\end{array}$ \\
\hline 1 &, 684 &, 468 &, 438 & 3,87974 \\
\hline
\end{tabular}

Dari tabel 9 diatas diketahui bahwa nilai $R$ Square adalah sebesar 0,468 atau 46,8\%. Artinya, Sistem Perpajakan dan Pemeriksaan Pajak dalam menjelaskan variasi perubahan variabel dependen Penggelapan Pajak adalah sebesar 46,8\%. Sedangkan sisanya 53,2\% (100\%-46,8\%) dipengaruhi oleh variabel lain yang tidak dianalisis dalam penelitian ini.

\section{Pembahasan Hasil Pengujian}

a. Pengaruh sistem perpajakan terhadap penggelapan pajak

Hasil uji koefisien determinasi, nilai $R$ Square dari model regresi diketahui bahwa nilai $R$ Square adalah sebesar 0,468 atau 46,8\%. Artinya, Sistem Perpajakan dalam menjelaskan variasi perubahan variabel dependen Penggelapan Pajak adalah sebesar 46,8\%. Sedangkan sisanya 53,2\% (100\%-46,8\%) dipengaruhi oleh variabel lain yang tidak dianalisis dalam penelitian ini. 
Dari hasil pengujian hipotesis pertama dilakukan dan menghasilkan nilai koefisien regresi sebesar 0,947 dan nilai signifikan $0,000<0,05$ sehingga uji hipotesis pertama menyatakan bahwa sistem perpajakan berpengaruh terhadap penggelapan pajak.

b. Pengaruh pemeriksaan pajak terhadap penggelapan pajak

Hasil uji koefisien determinasi, nilai $R$ Square dari model regresi diketahui bahwa nilai $R$ Square adalah sebesar 0,468 atau 46,8\%. Artinya Pemeriksaan Pajak dalam menjelaskan variasi perubahan variabel dependen Penggelapan Pajak adalah sebesar 46,8\%. Sedangkan sisanya 53,2\% (100\%-46,8\%) dipengaruhi oleh variabel lain yang tidak dianalisis dalam penelitian ini.

Dari hasil pengujian hipotesis kedua dilakukan dan menghasilkan nilai koefisien regresi sebesar $-0,951$ dan nilai signifikan $0,001<0,05$ sehingga uji hipotesis kedua menyatakan bahwa pemeriksaan perpajakan berpengaruh terhadap penggelapan pajak.

\section{KESIMPULAN DAN SARAN}

\section{Kesimpulan}

Hasil uji koefisien determinasi, nilai $R$ Square dari model regresi diketahui bahwa nilai $R$ Square adalah sebesar 0,468 atau 46,8\%. Artinya, Sistem Perpajakan dan Pemeriksaan Pajak dalam menjelaskan variasi perubahan variabel dependen Penggelapan Pajak adalah sebesar 46,8\%. Sedangkan sisanya 53,2\% (100\%-46,8\%) dipengaruhi oleh variabel lain yang tidak dianalisis dalam penelitian ini. Hasil pengujian hipotesis pertama dilakukan dan menghasilkan nilai signifikan $0,000<0,05$ sehingga uji hipotesis pertama menyatakan bahwa sistem perpajakan berpengaruh terhadap penggelapan pajak. Pada hasil pengujian hipotesis kedua menghasilkan nilai signifikan $0,001<0,05$ sehingga uji hipotesis kedua menyatakan bahwa pemeriksaan pajak berpengaruh terhadap penggelapan pajak. Dapat dikatakan bahwa semakin baiknya tingkat sistem perpajakan dan pemeriksaan pajak maka semakin berkurangnya tingkat penggelapan pajak.

\section{Saran}

1. Penelitian selanjutnya diharapkan dapat menambahkan variabel independen dalam penelitian mengenai tindakan penggelapan pajak. 
2. Peneliti pada bidang yang sama sebaiknya dapat memperluas ruang lingkup penelitian, misalnya pengambilan sampel lebih dari yang peneliti lakukan, sehingga diharapkan dapat meningkatkan keakuratan hasil penelitian.

3. Diharapkan perlu adanya sosialisasi sejak dini tentang pentingnya sikap wajib pajak untuk taat dan patuh dalam melaksanakan kewajiban perpajakan. Selain itu, perlu disosialisasikan secara luas manfaat dari uang pajak yang disetor ke kas negara.

4. Diharapkan semakin tinggi kesadaran masyarakat dalam membayar pajak secara benar, maka penggelapan pajak akan cenderung semakin rendah.

\section{UCAPAN TERIMA KASIH}

Dalam penyusunan penelitian ini, penulis menyadari bahwa tanpa bimbingan dan bantuan dari berbagai pihak, penulis belum tentu dapat menyelesaikan penelitian ini. Untuk itu ucapan terima kasih yang sebesarbesarnya penulis sampaikan kepada :

1. Bapak Febryandhie Ananda, SE, M.Si, selaku ketua STIE “KBP” Padang, yang membantu dan memberi saran bagi penulis.

2. Ibu Dewi Zulvia, SE, MM, selaku Ketua Prodi Akuntansi STIE"KBP" Padang dan sebagai Dosen Pembimbing Proposal Skripsi yang dengan kesabaran membimbing dan memberi arahan serta masukan yang sangat berguna bagi penulis sehingga skripsi ini dapat terselesaikan.

3. Ibu Lisa Amelia Herman, SE, M.Si selaku Penasehat Akademik Angkatan IX Program Studi Akuntansi STIE "KBP” Padang.

4. Bapak / Ibu Instansi yang telah ikut serta dalam mengisi kuesioner yang penulis bagikan.

\section{DAFTAR PUSTAKA}

Andito, D. (2016). Pengaruh Keadilan Dan Sistem Perpajakan Terhadap Penggelapan (Tax Evasion). Universitas Komputer Indonesia, Hal. 1-16.

Ardian, R. D., \& Pratomo, D. (2014). Pengaruh Sistem Perpajakan Dan Pemeriksaan Pajak Terhadap Penggelapan Pajak (Tax Evasion) Oleh Wajb Pajak Badan (Studi Pada KPP Pratama Wilayah Kota Bandung. Universitas Telkom, Hal. 1-10.

Ghozali, I. (2011). "Aplikasi Analisis Multivariate Dengan Program IBM SPSS 19, Edisi 5. In Semarang: Badan Penerbit Universitas Diponegoro.

Ghozali, I. (2016). Aplikasi Analisis Multivariete Dengan Program IBM SPSS 23. Semarang: Badan Penerbit Universitas Diponegoro.

Hidayat, N. (2012). Pemeriksaan Pajak. In Jakarta, PT. Alex Media Komputindo Kompas Gramedia.

Indriantoro, N., \& Supomo, B. (2002). Metodologi Penelitian Bisnis. 
Yogyakarta: BPFE-Yogyakarta.

Mardiasmo. (2009). Perpajakan Edisi Revisi 2009. Yogyakarta: Andi.

Masri, I., \& Martani, D. (2012). Pengaruh Tax Avoidence Terhadap Cost of Debt. PPJK 20. Tesis Fakultas Ekonomi Universitas Indonesia, Jakarta.

Priyastama, R. (2017). Buku Sakti Kuasai SPSS. Yogyakarta: Start Up.

Saraswati, V. A. (2013). Pengaruh Pemeriksaan Pajak dan Self Assessment System Terhadap Tax Evasion (Survei Pada Kantor Pelayanan Pajak di Lingkungan kanwil Jabar I). Universitas Komputer Akuntansi.

Siahaan, M. P. (2010). Hukum Pajak Material. Yogyakarta: Graha Ilmu.

Sugiyono. (2016). Metode Penelitian Kuantitatif, Kualitatif dan $R \& D$. Penerbit Alfabeta, Bandung.

Suminarsasi, W., \& Supriyadi. (2011). Pengaruh Keadilan, Sistem Perpajakan. Dan Diskriminasi terhadap Persepsi Wajib Pajak Mengenai Etika Penggelapan Pajak (Tax Evasion). Jurnal Simposium Nasional Akuntansi XV No. 672PAN-SNA15VII2012, Universitas Gadjah Mada, Yogyakarta.

Zulvia, D. (2013). Analisis Perhitungan Dan Pelaporan PPH Pasal 25 PADA PT SELAGO MAKMUR PLANTATION. Jurnal Kbp, 1(3), 1689-1699. https://doi.org/10.1017/CBO9781107415324.004 